\title{
Potential of two insectivorous avian species and two insect predators for spreading Spodoptera littoralis nucleopolyhedrovirus (S/NPV) in Egyptian ecosystem
}

\author{
Monir Mohamed El Husseini $1^{*}$ (D, Salama Ibrahim Askar ${ }^{2}$ and Ata Ahmed Ata ${ }^{1}$
}

\begin{abstract}
The polyhedral inclusion bodies (PIBs) of Spodoptera littoralis nucleopolyhedrosis virus (SINPV) were extracted from droppings of both the house sparrow Passer domesticus Raf. and the cattle egret Bubulcus ibis Bon. Due to the wide host range of the SINPV, the extracted PIBs were bioassayed versus newly hatched larvae (L1) of S. littoralis, S. exigua, Trichoplusia ni, and Autographa circumflexa belonging to the insect fauna of the Egyptian clover Trifolium alexandrinum L. and the greater wax moth Galleria mellonella. Mortality of treated neonates of the 5 tested insect species ranged between 80 and $100 \%$ after 7 days from ingesting the PIB-contaminated diet. Feeding nymphs and adults of the earwig Labidura riparia Pallas on S. littoralis larvae infected with the nuclear polyhedrosis virus (SINPV) passed viable PIBs in feces which were extracted and bioassayed versus lepidopteran larvae of L1. All of the virustreated 5 lepidopteran species became infected with the virus and showed mortality of 44-96\% at the 7th day post ingestion of the extracted PIBs. On the other hand, feces extract of the 3rd larval instar (L3) of the lacewing Parachrysopa pallens (R.) fed on the virus-diseased larvae of S. littoralis caused no mortality when assayed versus the 5 tested lepidopteran larvae proving absence of viable PIB polyhedra that might be due to the mode of larval feeding by external digestion of its host contents including the polyhedra. Results explain the potential role played by insectivorous birds in spreading the nucleopolyhedrosis viruses in the agroecosystem as well as certain predatory insects.
\end{abstract}

Keywords: Nucleopolyhedrosis virus, House sparrow, Cattle egret, Earwig, Lacewing, Dispersal, Lepidopteran pests

\section{Background}

The repeated natural occurrence of nucleopolyhedrosis viruses in populations of agricultural and forest insect pests is a fact pointing to existing and circulation of the virus in the agroecosystem. Without anthropogenic interference to disseminate the viruses as biological control agents against insect pests, there are other biological and physical factors or mechanisms playing a potential role in conserving and dispersing the occluded

\footnotetext{
*Correspondence: monirelhusseini45@gmail.com

'Center of Biological Control \& IPM, Faculty of Agriculture, Cairo University, Giza, Egypt

Full list of author information is available at the end of the article
}

entomopathogenic viruses in nature. Generally, the biological mechanism is the most common for dispersing the polyhedral inclusion bodies (PIBs) of the nucleopolyhedrosis viruses or occlusion bodies (OBs) of the granuloviruses in the agroecosystem. Spreading the PIBs and OBs occur by the predators which consume larvae infected with nucleopolyhedrosis or granulosis viruses which mostly excrete viable PIBs or OBs in their feces, cot, and droppings among the next day's post feeding on the diseased preys (Beekman 1980; Abbas and Bocias 1984; Young and Yearian 1987; Brooks 1993; and Vasconcelos et al. 1996). The physical mechanism is represented by natural enemies (predators and parasitoids) 
that become surface contaminated on mouthparts, legs, and body during feeding on the larvae infected with baculovirus or granuloviruses and thus physically disperse the PIBs or OBs on plant surfaces (Caballero et al. 1991, Sait et al. 1996; Escribano et al. 2000, and Lacey et al. 2015). The most important and potential mechanism for virus dissemination in different field crops and forest habitats was early demonstrated by predators from different taxa (Smirnoff 1959; Biever et al. 1982; Young and Yearian 1987, 1992; Entwistle et al. 1993, and Fuxa and Richter 1994). Under certain circumstances, natural enemies could play a role in triggering disease epizootics in lepidopteran insect pests' populations (Fuxa and Tanada, 1987 and Lacey et al. 2015).

The aim of the present work was to study the potential of two insectivorous avian and two insect predators in dispersing a nucleopolyhedrosis virus by testing the presence of viable PIBs of the Spodoptera littoralis nucleopolyhedrosis virus (SlNPV) in droppings of the insectivorous cattle egret Bubulcus ibis Bon. (Pelecaniformis: Ardaeidae) and the house sparrow Passer domesticus Raf. (Passeriformis: Passeridae) versus newly hatched larvae of the noctuid's cotton leafworm Spodoptera littoralis (Boisd.), the beet worm S. exigua L., the semi-loopers Trichoplusia ni (Hübner) and Autographa circumflexa (L.), and the pyralid greater wax moth Galleria mellonella $\mathrm{L}$. Also, it is to prove the presence or absence of PIBs in feces of the predatory labidurid earwig Labidura riparia Pallas and the chrysopid lacewing Parachrysopa pallens (R.) when adults and nymphs of the 1st predator and larvae (L3) of the 2nd one fed experimentally on $S$. littoralis virus-infected larvae.

\section{Material and methods}

\section{Habitat description and field treatment}

Accidentally, during a visit to a large area planted with the Egyptian clover Trifolium alexandrinum L. at Al Badrashin village in Giza governorate in April 2019 to collect nymphs and adults of the earwig Labidura riparia Pallas for studies, the field was found highly infested with the cotton leafworm Spodoptera littoralis (Boisd.), S. exigua L., and few larvae of the semi-loopers Trichoplusia ni (Hübner) and Autographa circumflexa (L.). The semi-loopers were found on wild plants of Cruciferae in the clover field. Two trees of mulberry (Morus alba L.) were standing in the middle of the field on which a swarm of the house sparrow was resting and fly landing in the field feeding on the lepidopteran larvae visible on the clover plants. This behavior is repeated several times a day. Many trees of nearly 20-m-high white willows Salix tetrasperma Roxb. (Calicaceae) are growing along the irrigation canal adjacent to the field. A colony of the cattle egret Bubulcus ibis Bon. inhabited these Salix trees. When the clover field is irrigated after cutting, a large number of the $B$. ibis was found in the field feeding vigorously on the floating insects especially on the lepidopteran larvae. By evening, the house sparrows overnight on the mulberry trees and the cattle egret on the white willow trees. Under both tree species, a large number of droppings were excreted by these birds. Thus, the idea of the present study was born. The field under the mulberry trees and the area adjacent to the irrigation canal was sprayed at the evening by the nucleopolyhedrosis of $S$. littoralis at the concentration of $5 \times 108 \mathrm{PIBs} / \mathrm{ml}$, and after 6 days (1-2 days shorter than the virus infected larvae die), the clover was cut and the field was irrigated to attract more $B$. ibis for feeding on the floated and moribund larvae infected with the virus in order to collect and test the following droppings for presence of viable virus PIBs.

\section{Collecting bird droppings}

Plastic sheets were placed under the mulberry and white willows trees at the 6th day post application of the S. littoralis nucleopolyhedrosis virus (SlNPV). As previously mentioned, this period is required as not full incubation period (moribund larvae) enabling infection with the virus and its replication in cell nuclei of nearly most larval body tissues before death and rupture of the body cuticle. Six days post treatment with SlNPV, the clover foliage was cut as green fodder for farm animals, and the field was flooded by irrigation water, a routine practice after cutting the clover. This agricultural practice enforces any insects in soil cracks or under the remaining cut clover including the diseased larvae to float on the water surface, which attract a large number of the cattle egret $B$. ibis to visit the field and vigorously feed on them as well as did the house sparrow $P$. domesticus. The birds excrete most of their droppings at night; droppings were collected in the early morning from the plastic sheets placed under the trees at the 2nd, 3rd, and 4th days post irrigation, kept in paper bags, and transferred to the laboratory.

\section{Extraction of PIBs from bird droppings}

The collected droppings of the 3 days were mixed well together, and $50 \mathrm{~g}$ from droppings of each bird species were soaked in $100 \mathrm{ml}$ distilled water and homogenized by vortexing for $5 \mathrm{~min}$ to disrupt any clumping in. The homogenized dropping suspensions were passed for primary filtration through 4 layers of muslin cloth. The filtrate was centrifuged at $900 \mathrm{rpm}$ for $2 \mathrm{~min}$ to remove the undigested insect pats and debris. The supernatant was further centrifuged at $5000 \mathrm{rpm}$ for $10 \mathrm{~min}$. The pellet containing the polyhedral inclusion bodies (PIBs) was resuspended in $5 \mathrm{ml}$ sterile distilled water as stock suspension, and the PIB concentrations were counted using a 
hemocytometer. The stock suspensions of PIBs were refrigerated at $4{ }^{\circ} \mathrm{C}$ until needed for the tests.

\section{PIB extraction from feces of $L$. riparia and $P$. pallens} Both adults and nymphs (130 individuals) of L riparia and 3rd instar larvae of P. pallens were offered S. littoralis NPV-diseased larvae, which were 6 days previously infected with SlNPV to enable multiplication of the virus and formation of PIBs in nuclei of all tissue cells of the body. The feces particles were separated from the butter paper furnished in the Petri dishes by means of a sculpt on the 1st day post feeding on diseased prey and shifted into sterilized test tube. Feces were collected for 3 successive days parallel to feeding on S. littoralis-diseased larvae. The daily excreted feces of each predatory species were mixed together and suspended in $1 \mathrm{ml}$ sterilized distilled water. The suspension was homogenized by vortexing for $3 \mathrm{~min}$ followed by centrifugation at $900 \mathrm{rpm}$ for $2 \mathrm{~min}$ to remove the debris, and the supernatant was further centrifuged at $5000 \mathrm{rpm}$ for $10 \mathrm{~min}$ to extract the PIBs of the SlNPV, where the pellets here were resuspended each in $1 \mathrm{ml}$ sterilized distilled water and kept at $4{ }^{\circ} \mathrm{C}$.

\section{Rearing of test insects}

Field-collected larvae of the 4 species, S. littoralis, S. exigua, T. ni, and A. circumflexa, were reared on the standard diet described by Shorey and Hale (1965). G. mellonella was reared on a simple diet according to Ibrahim et al. (1984). Adults and nymphs of the earwig $L$. riparia were collected from soil barrows at borders of the clover field, placed in a 2-L plastic container, filled with paper strips, to avoid cannibalism, and transported to the laboratory. Individuals were confined solitary in Petri dishes furnished with butter paper and supplied daily with young larvae of reared $S$. littoralis. This predator has only 3 generations/ 2 years (El Husseini 1969). Accordingly, adults and nymphs develop in a long period of many months. Thus, the field-collected specimens were used as wild individuals in the test. Adults of the lacewing P. pallens were collected by a light trap and reared as described by Abou-Bakr (1989). Larvae were fed first on aphids (Aphis craccivora Koch) till reaching the 3rd larval instar (L3), and then fed on young larvae of $S$. littoralis. All test insects were reared or maintained under laboratory conditions of $25-27^{\circ} \mathrm{C}$ and $60-7 \% \mathrm{RH}$.

\section{Bioassay of PIBs extracted from droppings}

From the wide host range highly concentrated stock suspension of $S$. littoralis viral PIBs extracted from droppings of each $B$. ibis and $P$. domesticus, 5 successive concentrations of $\left(1 \times 10^{4}, 1 \times 10^{5}, 1 \times 10^{6}, 1 \times 10^{7}\right.$, and $1 \times 10^{8} \mathrm{PIBs} / \mathrm{ml}$ ) were prepared in sterilized distilled water. Fresh uncontaminated leaves of clover were hanged on a standing holder and sprayed with the tested PIB concentration using a fine perfume hand atomizer and left to evaporate. The treated clover leaves were placed in Petri dishes (5 $\mathrm{cm}$ in diameter) furnished with butter paper. Each dish separately received 10 neonate larvae (L1) from the targeted noctuid insect pests, i.e., $S$. littoralis, S. exigua, T. ni, and A. circumflexa that left feeding on for $48 \mathrm{~h}$. Five replicates were set for each test. A control was set also in 5 replicates offering the larvae untreated clover leaves previously sprayed with sterilized distilled water. Then, the treated larvae and the control were provided daily with fresh untreated clover leaves for the next 5 days. Mortality among treatments and controls was recorded daily for 1 week post treatment. Concerning bioassay versus larvae of G. mellonella, $1 \mathrm{~g}$ of the diet was flat pressed on butter paper in thickness of $1 \mathrm{~mm}$ and sprayed with the tested PIBs desired concentration and then divided into 5 portions each on a disc of butter paper. The treated diet was shifted underlined with the butter paper into $2 \mathrm{oz}$ metal cups with caps and provided each with 10 neonate larvae of $G$. mellonella. They were left feeding on the treated diet and provided with new untreated if needed. The test runs in 5 replicates for each concentration, beside an untreated control. Mortality was also recorded among 7 days post treatment.

\section{Bioassay of PIBs extracted from insect predator's feces}

PIBs extracted from feces of $L$. riparia adults and nymphs were prepared in sterilized distilled water from the stock solution in concentrations of $1 \times 10^{1}, 1 \times 10^{2}$, $1 \times 10^{3}, 1 \times 10^{4}$, and $1 \times 10^{5} \mathrm{PIBs} / \mathrm{ml}$. The 5 PIB concentrations were administrated to the 4 targeted noctuid larvae on contaminated clover leaves by the same technique described for bioassay of those extracted from avian droppings, beside an untreated control with clover leaves previously sprayed with sterilized distilled water. The pyralid G. mellonella was bioassayed as previously described. Larvae were left feeding on the treated clover leaves for $48 \mathrm{~h}$ and supplied daily with fresh untreated leaves. Meanwhile, the wax moth larvae were provided with untreated diet if needed. Mortality was also recorded among 7 days post treatment. Although microscopic examination of the extracted pellet suspension obtained from larval feces of the chrysopid predator $P$. pallens showed absence of the PIBs of the S. littoralis nucleopolyhedrosis virus, it was tested versus the targeted lepidopteran larvae on clover leaves sprayed with this extract without dilution to assure absence of the PIBs parallel to untreated controls. It was also tested versus neonates of G. mellonella by mixing in the diet as previously described. The treatments and control were inspected daily in the next 7 days for registering any mortality appearing among the larvae of the test. 


\section{Statistical analysis}

Data were processed by analysis of variance using the Costat Statistical Software (1990).

\section{Results and discussion}

It is worth to mention that the PIB stock suspension extracted from droppings of the cattle egret $B$. ibis contained $8.25 \times 10^{11} \mathrm{PIBs} / \mathrm{ml}$ and that of the house sparrow $P$. domesticus contained $6.5 \times 10^{9} \mathrm{PIBs} / \mathrm{ml}$. This result indicated the high number of the consumed diseased S. littoralis larvae from the treated clover field by these insectivorous birds. This result is supported by that of Grzywacza et al. (1998) who reported that one larva of S. littoralis treated with SlNPV inoculum of $1 \times$ $10^{4}$ PIBs produced $1.86 \times 10^{9}$ polyhedral inclusion bodies (PIBs). In the present study, the inoculum applied in the clover field was with a concentration of $5 \times 10^{8}$ $\mathrm{PIBs} / \mathrm{ml}$. Also, the timing for cutting the virus-sprayed clover is very crucial to allow the presence of diseased larvae with complete body form (moribund) that float on the surface of irrigation water. If the clover cut was delayed for more than 6 days, the birds will not find a complete larval body to pick up. Because, after this period, death and body rupture of the diseased larvae occur and the body fluid is dispersed in the water and on the remains of the clover. This is also the same reason for selecting the correct harvesting time of diseased larvae when producing SlNPV in the laboratory for maximizing the yield of PIBs and avoiding losses from the death and rupture of larval bodies on the rearing diet (Gupta et al. 2007 and El Husseini et al. 2012).

\section{Bioassay of SINPV extracted from avian droppings}

As shown in Table 1, the lowest tested PIB concentration of $S l \mathrm{NPV}\left(1 \times 10^{4} \mathrm{PIBs} / \mathrm{ml}\right)$ extracted from the droppings of the cattle egret $B$. ibis induced mortality values in treated larvae of L1 reaching $88,80,84,86$, and $90 \%$ for $S$. littoralis, S. exigua, T. ni, A. circumflexa, and G. mellonella, at the 7th day post treatment, respectively. Meanwhile, the highest tested concentration $\left(1 \times 10^{8} \mathrm{PIBs} / \mathrm{ml}\right)$ resulted to a high efficacy recording mortality values of $96 \%$ in larvae of S. exigua and $100 \%$ in larvae of the other 4 lepidopteran species 7 days post treatment. Ignoffo (1966) and Bocias and Nordin (1977) found a decrease in larval mortality of Heliothis virescens and $H$. zea by increasing larval age, so that the values of LC50/ larval body weight increase greatly with progressing age, a phenomenon that could be attributed to a "dilution" effect of a constant viral dose (Fuxa and Tanada 1987). Thus, to test the extracted SlNPV versus larvae of L1 was preferred for 2 reasons: first, because of their availability in large numbers during laboratory rearing and, secondly, because of their high susceptibility to even the low concentrations of nucleopolyhedroviruses due to their low body weight.

Concerning the house sparrow $P$. domesticus that consumed virus-diseased larvae of $S$. littoralis, the birds passed viable PIBs in their droppings in amounts which successfully killed treated newly hatched larvae of the 5 treated lepidopteran species (Table 2). The results revealed mortality values of $88,80,86,90$, and $94 \%$ at the 7 th day post treatment with the lowest tested concentration $\left(1 \times 10^{4} \mathrm{PIBs} / \mathrm{ml}\right)$ in larvae (L1) of S. littoralis, $S$. exigua, T. ni, A. circumflexa, and G. mellonella, respectively. The concentration $1 \times 10^{7} \mathrm{PIBs} / \mathrm{ml}$ resulted in 96\% mortality among treated larvae of $S$. exigua and $100 \%$ among larvae of the other 4 species. Accordingly, statistical analysis showed no significant differences among mortality rates of the tested lepidopteran insects after the virus incubation period of 7 days, whatever with the highest or lowest tested concentrations.

Other insectivorous animals and birds play a potential role in spreading the occluded entomopathogenic viruses in nature. Lautenschlager and Podgwaite (1979) found experimentally that 5 species of insectivorous mammals and 3 species of birds passed polyhedral inclusion bodies (PIBs) of the gypsy moth (Lymantria dispar) nucleopolyhedrosis virus ( $L d \mathrm{NPV})$ through their alimentary tracts in their cot at amounts great enough to kill the gypsy moth, larvae in bioassays, which contribute to their

Table 1 Accumulated mortality \% in 5 lepidopteran species fed on Spodoptera littoralis nucleopolyhedrovirus extracted from droppings of Bubulcus ibis fed on diseased larvae

\begin{tabular}{|c|c|c|c|c|c|c|c|c|c|c|c|c|c|c|c|}
\hline \multirow[t]{3}{*}{$\mathrm{PIBs} / \mathrm{ml}$} & \multicolumn{3}{|c|}{ Spodoptera littoralis } & \multirow{2}{*}{\multicolumn{3}{|c|}{$\begin{array}{l}\text { Spodoptera exigua } \\
\text { Days post treatment }\end{array}$}} & \multirow{2}{*}{\multicolumn{3}{|c|}{$\begin{array}{l}\text { Phytometra ni } \\
\text { Days post treatment }\end{array}$}} & \multirow{2}{*}{\multicolumn{3}{|c|}{$\begin{array}{l}\text { Autographa circumflexa } \\
\text { Days post treatment }\end{array}$}} & \multirow{2}{*}{\multicolumn{3}{|c|}{$\begin{array}{l}\text { Galleria mellonella } \\
\text { Days post treatment }\end{array}$}} \\
\hline & \multicolumn{3}{|c|}{ Days post treatment } & & & & & & & & & & & & \\
\hline & 5 & 6 & 7 & 5 & 6 & 7 & 5 & 6 & 7 & 5 & 6 & 7 & 5 & 6 & 7 \\
\hline $1 \times 10^{4}$ & 40 & 74 & 88 & 40 & 76 & 80 & 34 & 70 & 86 & 36 & 70 & 90 & 48 & 82 & 94 \\
\hline $1 \times 10^{5}$ & 46 & 84 & 94 & 44 & 86 & 90 & 40 & 80 & 90 & 42 & 80 & 90 & 50 & 88 & 94 \\
\hline $1 \times 10^{6}$ & 50 & 86 & 94 & 46 & 88 & 94 & 46 & 88 & 96 & 44 & 86 & 96 & 58 & 90 & 100 \\
\hline $1 \times 10^{7}$ & 56 & 90 & 100 & 46 & 88 & 96 & 54 & 94 & 100 & 52 & 90 & 100 & 59 & 96 & 100 \\
\hline $1 \times 10^{8}$ & 56 & 90 & 100 & 52 & 90 & 100 & 54 & 94 & 100 & 52 & 90 & 100 & 60 & 94 & 100 \\
\hline Control & 00 & 00 & 00 & 00 & 00 & 00 & 00 & 00 & 00 & 00 & 00 & 00 & 00 & 00 & 00 \\
\hline
\end{tabular}


Table 2 Accumulated mortality \% in 5 lepidopteran species fed on Spodoptera littoralis nucleopolyhedrosis virus extracted from droppings of Passer domesticus fed on diseased larvae

\begin{tabular}{|c|c|c|c|c|c|c|c|c|c|c|c|c|c|c|c|}
\hline \multirow[t]{3}{*}{$\mathrm{PIBs} / \mathrm{ml}$} & \multirow{2}{*}{\multicolumn{3}{|c|}{$\frac{\text { Spodoptera littoralis }}{\text { Days post treatment }}$}} & \multirow{2}{*}{\multicolumn{3}{|c|}{$\frac{\text { Spodoptera exigua }}{\text { Days post treatment }}$}} & \multirow{2}{*}{\multicolumn{3}{|c|}{$\begin{array}{l}\text { Phytometra ni } \\
\text { Days post treatment }\end{array}$}} & \multirow{2}{*}{\multicolumn{3}{|c|}{$\begin{array}{l}\text { Autographa circumflexa } \\
\text { Days post treatment }\end{array}$}} & \multirow{2}{*}{\multicolumn{3}{|c|}{$\begin{array}{l}\text { Galleria mellonella } \\
\text { Days post treatment }\end{array}$}} \\
\hline & & & & & & & & & & & & & & & \\
\hline & 5 & 6 & 7 & 5 & 6 & 7 & 5 & 6 & 7 & 5 & 6 & 7 & 5 & 6 & 7 \\
\hline $1 \times 10^{4}$ & 42 & 74 & 88 & 40 & 76 & 80 & 38 & 76 & 84 & 38 & 70 & 86 & 50 & 82 & 90 \\
\hline $1 \times 10^{5}$ & 46 & 88 & 90 & 46 & 84 & 84 & 44 & 82 & 98 & 44 & 80 & 88 & 56 & 88 & 92 \\
\hline $1 \times 10^{6}$ & 46 & 90 & 92 & 46 & 84 & 90 & 48 & 86 & 98 & 48 & 88 & 94 & 58 & 90 & 98 \\
\hline $1 \times 10^{7}$ & 54 & 90 & 100 & 56 & 86 & 96 & 50 & 92 & 100 & 50 & 90 & 100 & 60 & 92 & 100 \\
\hline $1 \times 10^{8}$ & 56 & 90 & 100 & 56 & 88 & 96 & 50 & 94 & 100 & 52 & 90 & 100 & 60 & 92 & 100 \\
\hline Control & 00 & 00 & 00 & 00 & 00 & 00 & 00 & 00 & 00 & 00 & 00 & 00 & 00 & 00 & 00 \\
\hline
\end{tabular}

ability to passively transport NPV within agricultural and forest ecosystems. Also, Enwistle et al. (1993) proved that the insectivorous birds spread the nucleopolyhedrovirus of the pine beauty moth Panolis flammea in the environment triggering epizootics among its populations.

\section{Bioassay of S/NPV extracted from feces of $L$. riparia and $P$. pallens}

The results presented in Table 3 showed that adults and nymphs of the earwig L. riparia which consumed larvae of $S$. littoralis infected with SlNPV had passed the viable PIBs in their feces. Generally, the lowest concentration $\left(1 \times 10^{1} \mathrm{PIBs} / \mathrm{ml}\right)$ induced mortality rates between 44 and $50 \%$ among larvae (L1) of the 5 tested lepidopteran species at the 7 th day post treatment. The highest tested concentration $\left(1 \times 10^{5} \mathrm{PIBs} / \mathrm{ml}\right)$ resulted in 92, 82, 96, 90, and $94 \%$ mortality rates of larvae of S. littoralis, $S$. exigua, T. ni, A. circumflexa, and G. mellonella on the 7th day post treatment, respectively, showing no significant differences between the tested insect species. Other species of earwigs proved spreading nucleopolyhedroviruses by passing through the alimentary canal when prayed on diseased lepidopteran larvae. The forficulid earwig Doru taeniatum spread PIBs of S. frugiperda NPV in maize fields (Castillejos et al. 2017).
Although in case of the lacewing $P$. pallens, no PIBs were microscopically observed in pellet suspension when extracted from feces of the 3rd instar larvae (L3), larvae of L1 of the 5 tested lepidopteran species were fed on diet treated with the stock concentration as such without dilution. No mortality appeared in treated larvae among the 7 days post ingestion of the treated diet. This result means the absence of SINPV viable PIBs in larval feces of these predatory species. We assume that predatory insects with acidic intestinal $\mathrm{pH}$ and chewing mouthparts like the earwig $L$. riparia ingest the diseased larvae and passed viable PIBs through the alimentary canal carried them into feces and thus were also able to spread the NPV in the agricultural ecosystem. This assumption was mentioned by Beekman (1980) for a nucleopolyhedrovirus.

On the other hand, it seems that the predatory lacewing $P$. pallens larvae with its piercing-sucking mouthparts associated with external digestion of its prey body contents before sucking them passed no viable PIBs through its alimentary canal into feces. Most probably, the enzyme complex including proteases injected by the predatory larvae into body of the virus-diseased larva digests the protein matrix of the polyhedral body (polyhedrin) as well as the virion membrane protein. Castillejos et al. (2017) found that larvae of the lacewing Chrysoperla rufilabris fed on larvae of $S$. frugiperda infected

Table 3 Accumulated mortality \% in 5 lepidopteran species fed on Spodoptera littoralis nucleopolyhedrosis virus extracted from feces of Labidura riparia fed on diseased larvae

\begin{tabular}{|c|c|c|c|c|c|c|c|c|c|c|c|c|c|c|c|}
\hline \multirow[t]{3}{*}{$\mathrm{PIBs} / \mathrm{ml}$} & \multirow{2}{*}{\multicolumn{3}{|c|}{$\frac{\text { Spodoptera }_{\text {littoralis }}^{\text {a }}}{\text { Days post treatment }}$}} & \multirow{2}{*}{\multicolumn{3}{|c|}{$\frac{\text { Spodoptera exigua }^{a}}{\text { Days post treatment }}$}} & \multirow{2}{*}{\multicolumn{3}{|c|}{$\begin{array}{l}\text { Phytometra } n i^{\mathrm{a}} \\
\text { Days post treatment }\end{array}$}} & \multirow{2}{*}{\multicolumn{3}{|c|}{$\begin{array}{l}\text { Autographa circumflexa }^{a} \\
\text { Days post treatment }\end{array}$}} & \multicolumn{3}{|c|}{ Galleria mellonella $a^{a}$} \\
\hline & & & & & & & & & & & & & Day & st tre & \\
\hline & 5 & 6 & 7 & 5 & 6 & 7 & 5 & 6 & 7 & 5 & 6 & 7 & 5 & 6 & 7 \\
\hline $1 \times 10^{1}$ & 00 & 34 & 48 & 00 & 32 & 46 & 00 & 36 & 48 & 00 & 16 & 44 & 00 & 36 & 50 \\
\hline $1 \times 10^{2}$ & 00 & 38 & 50 & 00 & 42 & 52 & 00 & 40 & 66 & 00 & 20 & 56 & 00 & 50 & 68 \\
\hline $1 \times 10^{3}$ & 00 & 44 & 58 & 00 & 46 & 56 & 00 & 52 & 78 & 00 & 22 & 62 & 10 & 58 & 72 \\
\hline $1 \times 10^{4}$ & 40 & 60 & 86 & 42 & 66 & 78 & 30 & 76 & 92 & 34 & 70 & 82 & 44 & 80 & 90 \\
\hline $1 \times 10^{5}$ & 46 & 78 & 92 & 48 & 70 & 82 & 38 & 82 & 96 & 44 & 78 & 90 & 52 & 86 & 94 \\
\hline Control & 00 & 00 & 00 & 00 & 00 & 00 & 00 & 00 & 00 & 00 & 00 & 00 & 00 & 00 & 00 \\
\hline
\end{tabular}

${ }^{a}$ Mortality values for bioassaying feces extract of $P$. pallens versus the same lepidopteran larvae were zero 
with SfNPV did not pass the PIBs into their feces. The present result concerning the lacewing $P$. pallens is in agreement with that of Castillejos et al. (2017). Meanwhile, predatory bugs with piercing-sucking mouthparts suck the body contents of their preys without external digestion, and due to the acidic $\mathrm{pH}$ of their alimentary tract, they pass viable PIBs of nucleopolyhedroviruses. The pentatomid bug Podisus maculiventris fed on diseased noctuid larvae of Anticarsia gemmatalis passed viable PIBs of $A g N$ NV in their feces (Biever et al. 1982 and Abbas and Bocias 1984) as well as the nabid bug Nabis roseipennis fed on A. gemmatalis virus-diseased larvae (Young and Yearian 1987).

\section{Conclusion}

The present study is a contribution supporting the role of two insectivorous birds (cattle egret Bubulcus ibis and house sparrow Passer domesticus) and an insect predator (earwig Labidura riparia) in passing the Spodoptera littoralis nucleopolyhedrovirus through their alimentary tract into droppings or feces spreading its PIBs in the agroecosystem. PIBs extracted from bird droppings and feces of the insect predator were found viable and killed larvae of 5 lepidopteran insect pests: Spodoptera littoralis, S. exigua, Trichoplusia ni, Autographa circumflexa, and Galleria mellonella. Larvae of the lacewing Parachrysopa pallens did not pass viable PIBs due the its feeding habit of the external digestion of prey body content before sucking it. Also, the study pointed the potential of insectivorous avian in the agroecosystem for spreading the entomopathogenic viruses and the presence of nesting trees around the fields specially to colonize the cattle egret $B$. ibis. Farmers collecting droppings of $B$. ibis from the ground under the bird colonies spreading them in the field as organic fertilizer are contributing directly to spreading occluded insect viruses in the agroecosystem.

\section{Abbreviations}

L1: 1st larval instar; L3: 3rd larval instar; LC50: Lethal concentration killing 50\% of treated individuals; LdNPV: Lymantria dispar NPV; NPV: Nuclear polyhedrosis virus; PIBs: Polyhedral inclusion bodies; SANPV: Spodoptera frugiperda NPV; SINPV: Spodoptera littoralis NPV

\section{Acknowledgements}

The authors thank Mr. M El Guindi for allowing the field study in his farm

\section{Authors' contributions}

The authors declare that Monir M. El Husseini carried out the bioassay tests with Salama A. Askar, analyzed the data, and wrote the manuscript and Ata A. Ata collected the field material and reared the lepidopteran insects and the insect predators. The author(s) read and approved the final manuscript.

\section{Authors' information}

M.M. El Husseini is the Director of the Center of Biological Control \& IPM at the Faculty of Agriculture, Cairo University, Giza, Egypt.

Funding

Not applicable.
Availability of data and materials

Not applicable.

Ethics approval and consent to participate

Not applicable.

\section{Consent for publication}

Not applicable.

\section{Competing interests}

The authors declare that they have no competing interests.

\section{Author details}

${ }^{1}$ Center of Biological Control \& IPM, Faculty of Agriculture, Cairo University, Giza, Egypt. ${ }^{2}$ Department of Plant Protection, Faculty of Agriculture,

Damanhur University, Damanhour, Egypt.

Received: 13 April 2020 Accepted: 29 July 2020

Published online: 11 August 2020

\section{References}

Abbas MST, Boucias DG (1984) Interaction between nuclearpolyhedrosis virus infected Anticarsia gemmatalis (Lepidoptera: Noctuidae) larvae and predator Podisus maculiventris (Say) (Hemiptera: Pentatomidae). Environ Entomol 13: $599-602$

Abou-Bakr, H.E., 1989. Biocycle of Parachrysopa pallens (R.) as influenced by nourishment on two different preys (Neuroptera: Chrysopidae). Proc. Int. Cont. Econ. Entomol., Cairo, Egypt, Dec. 11 - 24, 11: 25 - 31.

Beekman AG (1980) The infectivity of polyhedra of nuclear polyhedrosis virus ( $N$. P.V.) after passage through the gut of an insect predator. Experientia 36:858885

Biever KD, Adrews PL, Andrews PA (1982) Use of predator Podisus maculiventris, to distribute virus and initiate epizootics. J Econ Entomol 75:150-152

Bocias DG, Nordin GL (1977) Interinstar susceptibility of the fall web worm, Hyphantria cunea to its nucleopolyhedrosis and granulosis viruses. J Invertebr Pathol 30:6875

Broocks WM (1993) Host-prasitoid-pathogen interactions. In: Beckage NE, Thompson SN, Federici AA (eds) Parasitoids and Pathogens of Insects. Vol. 2 Pathogens. Academic Press, San Diego, CA, USA, pp 231-272

Caballero P, Vargas-Osuna E, Santiago-Alverez C (1991) Parasitization of granulosis-virus infected and non-infected Agrotis segetum larvae and the virus transmission by three hymenopteran parasitoids. Entomol Exp Appl 58: $55-60$

Castillejos V, Garcia L, Cisneros J, Goulson D, Cave RD, Caballero P, Williams T (2017) The potential of Chrysoperla rufilabris and Doru taeniatum as agents for dispersal of Spodoptera frugiperda nucleopolyhedrovirus in maize. Entomol Experim et Appli 98:353-359

Costat Statistical Software (1990) In: Howard PH (ed) In Hand Book of Environmental Degradation Rates. CRS Press, Mar 28, 1991, p 776.

El Husseini M M (1969) Morphological and biological studies on the earwig, Labidura riparia Pallas (Dermaptera: Labiduridae). M.Sc. thesis, Faculty of Agriculture, Cairo University, pp.180.

El Husseini MM, Draz KAA, El-Aw MA, Kasem AS (2012) Testing some natural additives as protectants for Spodoptera littoralis nuclearpolyhedrovirus from sunlight inactivation. Egypt. J. Biol. Pest Control 22(2):191-196

Entwistle PF, Forkner AC, Green BM, Cory JS (1993) Avian dispersal of nuclear polyhedrosis viruses after induced epizootics in the pine beauty moth, Panolis flammea (Lepidoptera: Noctuidae). Biological Control 3:61-69

Escribano A, Williams T, Goulson D, Cave RD, Caballero P (2000) Parasitoidpathogen-pest interaction of Chelonus insularis, Campolitis sonorensis and a nucleopolyhedrovirus in Spodoptera frugiperda larvae. Biol Contr 19:265-273

Fuxa JR, Richter AR (1994) Distance and rate of spread of Anticarsia gemmatalis (Lepidoptera: Noctuidae) nuclear polyhedrosis virus released into soybean. Environ Entomol 23:1308-1316

Fuxa J R, Tanada Y (1987) Epizootiology of insect diseases (eds.). John Wily \& Sons, Inc., NY, USA, pp. 107.

Grzywacza D, Jonesa K.A, Moawad G, Cherrya A (1998) The in vivo production of Spodoptera littoralis nuclear polyhedrosis virus. Journal of Virological Methods, 71(1): 115-122. 
Gupta RK, Raina JC, Monobrullah MD (2007) Optimiztion of in vivo production of nucleopolyhedrovirus in homologus host larvae of Helicoverpa armigera. Journal of Entomology 4(4):279-288

Ibrahim SH, Ibrahim AA, Fayad YH (1984) Studies on mass rearing of the greater wax moth, Galleria mellonella L. and its parasite, Apanteles galleriae W. with some biological notes on the parasite. Agric Res Rev 62(1):349-353

Ignoffo C (1966) Effect of age on mortality of Heliothis zea and Helioyhis virescens larvae exposed to a nuclear-polyhedrosis virus. J Invertebr Pathol 8(2):279-282

Lacey LA, Grzywacz D, Shapiro-ILAN DI, Frutos R, Brownbridge M, Goettel MS (2015) Insect pathogens as biological control agents: back to the future. J. Invert. Pathol. 132:1-41

Lautenschlager RA, Podgwaite JD (1979) Passage of nucleopolyhedrosis virus by avian and mammalian predators of the gypsy moth, Lymantria dispar. Environ Entomol 8(2):210-214

Sait SM, Begon M, Thompson DJ, Harvey JA (1996) Parasitism of baculovirusinfected Plodia interpunctella by Venturia canescens and subsequent virus transmission. Functional Ecology 10:586-591

Shorey HH, Hale RL (1965) Mass rearing of the larvae of nine noctuid species on a simple artificial medium. J Econ Entomol 58:522-524

Smirnoff WA (1959) Predators of Neodiprion swainei Midd. (Hymenoptera: Tenthredinidae) larval vectors of virus diseases. Canadian Entomologist 91: 246-248

Vasconcelos SD, Williams T, Hails RS, Cory JS (1996) Prey selection and baculovirus dissemination by carabid predators of Lepidoptera. Ecol Entomol 21:98-104

Young SY, Yearian WC (1987) Nabis roseipennis adults (Hemiptera: Nabidae) as disseminators of nuclear polyhedrosis virus to Anticarsia gemmatalis (Lepidoptera: Noctuidae) larvae. Environ Entomol 16:1330-1333

Young SY, Yearian WC (1992) Movement of nuclear polyhedrosis virus into velvet bean caterpillar (Lepidoptera Noctuidae) larvae populations on soybean by Nabis roseipennis (Heteroptera: Nabidae). Journal of Entomological Science 27:126-134

\section{Publisher's Note}

Springer Nature remains neutral with regard to jurisdictional claims in published maps and institutional affiliations.

\section{Submit your manuscript to a SpringerOpen ${ }^{\circ}$ journal and benefit from:}

- Convenient online submission

- Rigorous peer review

- Open access: articles freely available online

High visibility within the field

- Retaining the copyright to your article

Submit your next manuscript at $\boldsymbol{\nabla}$ springeropen.com 